\title{
ALF ROSS SOM STRAFFRÄTTSFILOSOF ${ }^{1}$
}

\author{
Av Кiмmo Nuotio
}

Alf Ross (1899-1979) from Denmark is among the most highly regarded figures in the history of Nordic legal philosophy. Ross developed his views on the philosophy of law over several decades, starting from a Kelsenian concept, then moving to the so-called Scandinavian Realism, and subsequently turning towards a more linguistically-oriented analytical philosophy of law. The scientific work of Alf Ross covered many academic fields of legal study. In the 1960's and 1970's, ,the analytical philosopher "Ross became interested in questions of criminal liability. The current article traces the development of Ross 'work in order to provide a context to his writings on criminal liability. In the earlier period of Scandinavian Realism, other researchers, such as A.V. Lundstedt and P.O. Ekelöf, had developed critical ideas about traditional views on criminal liability and the justification of punishment. The author wishes to claim that the critical moral philosophy of the Scandinavian Realists was not totally irrelevant for Ross when he started writing on issues of criminal law. From the point of view of the philosophy of criminal law, Ross 'book, Skyld, Ansvar og Straf (1970; On Guilt, Responsibility and Punishment), is the most important. Its main ideas, such as the intimate connection between moral and legal liability, are presented in the current article. The last part of the article touches upon the influence of Ross' thought on Nordic theoretical discussions. *

\section{Allmänt om Ross som rättsfilosof}

Om man skulle vara tvungen att nämna enbart ett namn som svar på frågan, vem som internationellt sett är den mest kända nordiska rättstänkaren genom tiderna, skulle säkert mången komma att tänka på Alf Ross (1899-1979). Och inte utan orsak: hans verk hör till fundamentallitteraturen inom 1900-talets rättstänkande liksom även Hans Kelsens och H.L.A. Harts verk. Om nu Kelsens verk förkroppsligar den strikta, neokantianska och filosofiskt inriktade versionen av rättspositivismen, kunde Harts rättspositivism kallas mera sociologiskt och språkfilosofiskt inriktad. I såväl Kelsens som Harts rättsfilosofiska texter finns en relativt stabil grundton som består under flera årtionden. T.ex. Kelsens massiva produktion sträcker sig över ungefär en 60 års tidsperiod. Vissa grundåskådningar som på sätt och vis anteciperar den rena rättsläran går att finna redan i hans första större verk. Hart efterlämnade inte en lika massiv produktion som Kelsen och arbetade inte heller i ett så stort format som Kelsen, men t.ex. hans The Concept of Law (1961) är säkert ett nyckelverk om man beaktar den starka

\footnotetext{
* Title in English: Alf Ross as a Philosopher of Criminal Law. Original in Swedish.
} 
språkfilosofiorienteringen inom rättsvetenskapen under 1960- och 1970-talet. Kelsen skrev inte särskilt mycket om straffrätt, även om han ofta i generella sammanhang diskuterade också straffrättsteoretiska problem. Harts straffrättsfilosofiska essäer är givetvis en viktig del av hans produktion.

Det är inte lika lätt att karakterisera Alf Ross som rättstänkare som fallet är beträffande Kelsen och Hart. Ross skrev flere massiva böcker under en tidsperiod på 50 år (1929-1979). Hans första omfattande verk publicerades på tyska, Theorie der Rechtsquellen (1929). I den första delen av verket utförs en historisk och deskriptiv studie om rättskällelärorna efter början av 1800-talet. I den andra delen behandlas sedan teorierna systematiskt.

Vinding Kruse ansåg att Ross' verk alltför mycket var skrivet under kelsensk påverkan. Därför var Ross tvungen att vända sig till Hägerström och disputera $i$ Uppsala. ${ }^{3}$ Detta var naturligtvis viktigt därför att Ross på detta sätt redan tidigt kom in i den inre kretsen av skandinaviska realister.

Den unga Ross var extremt produktiv. År 1933 publicerade han verket Kritik der sogenannten praktischen Erkenntnis. Redan detta verk är en massiv kritik av de normativa etiska teorierna som utformats i kantiansk anda och andra liknande metafysiska rättsvetenskapliga teorier. År 1934 disputerade Ross i Köpenhamn med verket Virkelighed og Gyldighed $i$ Retslceren. Den publicerades senare i omarbetad form under titeln Towards a Realistic Jurisprudence (1946). Hans kanske mest kända bok Om ret og retfardighed publicerades år 1953; On Law and Justice (1959). På 1950-talet författade han också läroböcker i statsförfattningsrätt och folkrätt.

År 1968 utkom verket Directives and Norms, i vilket bl. a. olika sätt att använda språket undersöks. Boken präglas av ett logisk-analytiskt synsätt. Ross utvecklar där sin syn på den nya branschen, den deontiska logiken, som hade väckt uppmärksamhet efter grundläggande forskning av finländaren Georg Henrik von Wright. På 1960-talet blev Ross intresserad av de straffrättsliga frågornas filosofiska och andra grundläggande dimensioner, vilket ledde till en rad uppsatser på detta område. År 1970 utkom Skyld, Ansvar og Straf, vilken senare år 1975 publicerades på engelska under titeln On Guilt, Responsibility and Punishment. På grund av just denna bok är Ross allmänt känd som straffrättsteoretiker och straffrättsfilosof. År 1974 återkom Ross till dessa frågor med boken Förbrydelse och straf. I denna bok behandlas särskilt olika frågor gällande straffrättens allmänna läror. Här närmar man sig således mera straffrättsdogmatiska frågor. Ännu under sitt sista levnadsår 1979 lät den 80-årige Ross på tyska publicera en rättsjämförande undersökning om uppsåtet under namnet Über den Vorsatz.

Redan i början av 1930-talet hade Ross alltså inlett den kritik av metafysiskt och idealistiskt tänkande som var karakteristisk för hela Uppsala-skolan. Det är inte möjligt för mig att här gå in på uppkomsten av Uppsala-skolan, men det är inte heller möjligt att helt förbigå den. Det är nämligen värt att notera att det var den 
mogna, ytterst erfarna och kompetenta rättsfilosofen Ross som ganska sent i sitt liv - mot slutet av 1960-talet - blev intresserad av straffrätt. ${ }^{4}$ Det är mycket rimligt att anta att Ross' bakgrund på ett eller annat sätt också kommer till synes i hans verksamhet på straffrättens område. Detta är en omständighet som man inte alltid tillräckligt uppmärksammar. Det är för all del möjligt att detta samband tidigare har varit så självklart för nordiska straffrättsforskare att det inte har krävt någon explicit uppmärksamhet. Men nuförtiden läser man varken Ross' allmänna rättsfilosofi eller hans straffrättsfilosofi särskilt intensivt. Endast den allra äldsta generationen minns honom fortfarande som en levande forskare. Därför kan det vara mödan värt att säga någonting om förhållandet mellan hans rättfilosofi och hans straffrättsfilosof iska åsikter. $\mathrm{Nu}$, hundra år efter hans födelse och tjugo år efter hans död, är det också viktigt att försöka formulera några tankar kring hans tänkande och dess inflytande på den nordiska straffrättsteorin. För min del är det särskilt viktigt att kunna peka på ett visst inflytande på den finska teorin.

\section{Uppsala-skolan}

Det finns relativt mycket forskning kring uppkomsten och utformningen av den filosofiska s.k. Uppsala-skolan och den åtminstone delvis därmed sammanhängande rättsteoretiska och rättsfilosofiska riktningen, som senare fick bära namnet den skandinaviska realismen. ${ }^{5}$ Centralfiguren på det filosofiska planet var Axel Hägerström, vars filosofi uppkom som en stark kritik av den ännu dårådande boströmska rationella idealismen. ${ }^{6}$

Utan att gå närmare in på detaljer måste det påpekas att Hägerström ville rikta den vetenskapliga forskningen mot något helt nytt: vetenskapen borde i stället för att koncentrera sig på olika ideella begrepp, principer osv. koncentrera sig på det verkliga, alltså på verkligheten. Hägerströms mål var att bevisa att det finns en objektiv, existerande verklighet, vars existens inte är beroende av iakttagelser. Hans idé var att gamla metafysiska idealistiska åskådningar enbart kan övervinnas genom en filosofisk grundsyn om verklighetens existens, dvs. ontologin. Hägerström förnekade alla dualistiska versioner av ontologin, i vilka man på något sätt kombinerar olika ontologiska kategorier. Hägerströms ontologi har kallats metafysisk monism. Detta betydde också att vetenskapen alltid skall använda empiriska metoder. Men på det kunskapsteoretiska planet var Hägerström inte en ren empirist, utan han medgav att det finns begrepp och kategorier som så att säga är förutsättningar för att man över huvud taget kan nå kunskap om det verkliga. Olika speciella vetenskapsgrenar skall enligt Hägerström undersöka verkligheten genom empiriska metoder. Men filosofin skall enligt honom utreda betingelserna för empirins existens, vilket betyder att filosofins metoder inte kan vara empiriska. Filosofin skall använda begreppsliga analyser. ${ }^{7}$

Den hägerströmska filosofin var med säkerhet banbrytande i sin materialistiska inriktning. Vetenskapen skall koncentrera sig på det reella, och filosofin måste kunna ge den vetenskapliga forskningen en riktig teori om verkligheten. Enligt 
Uppsala-skolan kan vetenskapens hela uppgift definieras enligt följande: vetenskapen skall framställa riktiga påståenden om verkligheten. Riktiga påståenden har alltså referens till verkligheten.

Värdeteorin var en av Uppsala-skolans främsta framgångar. Här var kritiken av metafysiken hårdast. Värderingar ansågs vara sammankopplade med känslor. En känsla ansågs inte vara något medel för att nå kunskap om verkligheten. Varken värden eller normer existerar i egentlig mening och därför kan man inte heller formulera sanna eller falska påståenden beträffande deras verklighet. Enligt Hägerström är alla objektivistiska eller metaetiska värdeteorier falska. Men vilken mening har då sådana utsagor vari det talas om värden? Teoretiskt kan de inte vara sanna eller falska, men praktiskt kan de ha en viss betydelse. Enligt Hägerströms emotivistiska värdeteori betyder sådana utsagor att de är uttryck för vissa känslor. I det praktiska livet kan alltså moraliska värdeutsagor ha en betydelse trots att det varken kan finnas någon normativ etik eller någon juridisk teori om rättsnormernas objektiva giltighet.

Efter att ha stiftat bekantskap med Hägerströms tänkande föresatte sig Ross att granska följande problematik: I vilken mening kan man veta någonting om värden? Hur är värdeutsagorna meningsfulla? I Kritik der sogenannten praktischen Erkenntnis anför Ross en grundläggande kritik av existerande etiska teorier. Och det finns inte mycket som undgår hans kritik: t. ex. alla former av pliktetik måste uppges. Ord som plikt och värde är meningslösa, men detta betyder inte att de också skulle vara uttryckslösa. När någon säger att han eller hon är förpliktad till någonting, är detta bara ett rationaliserat uttryck om en irrationell upplevelse. "Den faktiska moralen är inte ett uttryck av kunskap (sann eller falsk) och den s.k. etiken är ingen vetenskap, det är ingen vetenskap om vad som i praktiken är "giltigt". All spekulation om vad som är giltigt i praktiken är bara kunskapsillusion, ett intellektuellt Fata morgana,..."

I detta skede var Ross ännu aktiv huvudsakligen på det filosofiska planet; den juridiska tillämpningen fick ännu vänta. Men han var inte den enda filosofen eller juristen som vid den här tidpunkten entusiastiskt försökte använda sig av Hägerströms filosofiska och vetenskapsteoretiska slutledningar och visa vägen för andra. De två andra mest aktiva hette Karl Olivecrona och Vilhelm Lundstedt. Jag vill här gå närmare in bara på Lundstedts insats.

Enligt Lundstedt är straffrätten egentligen bara ett försök att klä det irrationella medvetandet $i$ en skenbart verklighetstrogen och vetenskaplig dräkt. Lundstedt betonade särskilt att skuldteorierna måste ges en ny mening. Han kritiserade häftigt t.ex. Mezgers idéer om att domaren genom att tillägga sitt eget rättsliga skuldomdöme kunde på något sätt "höja" den psykologiska skulden hos brottslingen på en högre och objektivare nivå. Lundstedt trodde inte på detta eftersom det skulle förutsätta att det är möjligt att uppnå objektiva omdömen beträffande värdeutsagor. Enligt Lundstedt är det metafysiska tänkandet skadligt för hela synsättet på straffrätten: ett straff har nämligen inte alltid en de facto 
moralbildande verkan utan ofta är det snarare tvärtom. Han kritiserade t.ex. frirättsskolan för att dessa forskare inte förstår "rättsmekanismernas realiteter".

Enligt Lundstedt kan inte heller någon legitimering av straffrättslig rättspraxis härledas ur rättviseprinciper. Det enda som legitimerar straffrättsliga normer och sanktioner är att de är oundvikliga i samhället. Det finns alltså ingen annan grund för straffrätten som rättsvetenskapen kunde klarlägga. Straffrätten uppfyller vissa praktiska funktioner som räcker till för att legitimera rättspraxis. Det kan kanske uppmärksammas att Lundstedts polemik har vissa likheter med de krav som presenterades av den tidigare sociologiska skolan (von Liszt m.m.), som också riktade kritik mot detta att man (särskilt inom den s.k. klassiska skolan) inte förstod att de straffrättsliga sanktionernas legitimering går att söka i deras nödvändighet för att skydda samhället inför det hot som brottslingarna utgör. Men Lundstedts kritik hade en annan bakgrund än vad den sociologiska skolan hade. Uppsalaskolans filosofer och jurister hade en filosofisk teori om verkligheten; det var fråga om en kritik av den juridiska begreppsbildningen. Det var däremot inte fråga om att sammankoppla kriminologiska uppgifter, kriminalpolitiska funktioner och straffrätten som ett juridiskt normsystem, vilket var meningen inom den sociologiska skolan.

Också för Lundstedt handlade det om ett slags "social engineering" i straffrätten, men enligt honom hörde t.ex. lärorna om specialpreventionen till en förgången värld. Den sociologiska skolan betonade mera direkt bekämpandet av samhällsfarligheten hos brottslingar, medan det enligt Lundstedt var fråga om att rikta det straffrättsliga och moraliska klandret mot brottsliga handlingar i stället för mot brottslingar. Idén var ett pragmatiskt, moraliskt synsätt på straffrätten och att straffet förutsätter en klar handlingsorientering. Den moraliska dimensionen går förlorad, om man enbart anser brottslingar vara en källa av faror för samhället. ${ }^{10}$

Det är viktigt att här ännu påpeka att Lundstedts egna åsikter om "rättsmekanismernas realiteter" var relativt moderna. Strafflagens egentliga funktion ses i straffrättens moralbildande verkningar, inte i avskräckning. Den teori om straffrättens generalpreventiva funktioner, som utvecklas hos Lundstedt (1936), är en tillämpning av Hägerströms analys om pliktkänslor. Det faktum att folk sällan bryter straffrättsligt sanktionerade förbud, när detta lätt skulle vara möjligt, måste ses som ett bevis för straffrättens moralbildande verkan. Annars kunde laglydighetens mirakel inte förklaras. Det måste därför finnas mekanismer som förorsakar att det bland befolkningen uppstår känslor som hindrar dem från att begå brott. Straffrättsliga normer och utdömande av straff ses alltså så att säga som former av omedveten samhällsstyrning, propaganda. Här kommer social engineering -tanken till synes. Den moral som straffrätten påtvingar människorna är inte ideell utan reell; det skulle vara mycket svårt att väcka känslor beträffande sådana förbud och påbud som skulle sakna en reell bakgrund bland befolkningens rättsmedvetande. 
En annan teoretiker som på sitt sätt utvecklade uppfattningen om att värden på det straffteoretiska planet närmast har med emotioner att göra är naturligtvis den unge Per-Olof Ekelöf. Också han kan sägas ha stått nära Uppsala-skolan. I sitt arbete från år 1942 "Straffet, skadeståndet och vitet" undersökte han grundligt olika sanktioners allmänpreventiva moralbildande verkningssätt med en explicit utgångspunkt i Hägerströms (och Westermarcks) moralteori. " Den emotivistiska moraluppfattningen sammankopplades med någon slags funktionalistisk social engineering -uppfattning om makt och styrning av samhället. Ekelöf skriver om straffets moralbildande verkan på ett sätt som säkert var ett stort framsteg på sin tid. Den kunde även i dagens diskussioner mötas med en viss förståelse. Han skriver bl.a. ${ }^{12}$ :

"Frågan är nu hur straffet kan väcka och vidmakthålla... medborgarnas pliktkänsla. ... vi måste uppmärksamma att straffet av medborgarna uppfattas icke blott som en brottsprevenerande åtgärd utan även som ett uttryck för samhällets ogillande av det begångna brottet. ... Straffet uttrycker emellertid icke blott samhällets moraliska indignation mot brottet, utan väcker även denna känsloreaktion hos allmänheten. För att förstå hur detta är möjligt, måste vi beakta att känslouttrycken överhuvudtaget kunna utnyttjas icke blott för att ge uttryck åt en känsla utan även för att väcka en motsvarande känsla hos andra. ...straffet såsom uttryck för den organiserade samhällsmaktens moraliska ogillande av brottet måste ha förmåga att väcka ett motsvarande ogillande hos allmänheten. Ju regelbundnare straffmaskineriet fungerar ju starkare blir denna suggestion."

Redan Lundstedts åsikter talar för att den filosofiskt baserade kritiken av det traditionellt juridiska betraktelsesättet och den traditionella dogmatiken, vilka var viktiga för dem som kunde kallas representater för den skandinaviska realismen, inte ledde till någon extrem form av behavioristiskt synsätt på mänskligt handlande. Det var hela tiden möjligt att tillskriva de psykiska fenomenens värld en viss betydelse, även om man vetenskapligt inte kunde godkänna deras existens. Medelbart kunde de tillhöra verkligheten. Redan den tidiga språkfilosofin hos Hägẹrström präglades av en viśs psykologisering. Olika uttrycks betydelse bestämdes inte enbart genom företeelser som skulle kunna reduceras till iakttagelser, utan i stället förstod Hägerström hela teorin om uttryckens betydelser som ett slags mentalanalys. Uttrycken fick sin betydelse genom att vara uttryck för föreställningar, omdömen eller känslor. Alla omdömen var i själva verket mentala akter, även de vetenskapliga omdömena. Helin fäster uppmärksamhet vid att Hägerström egentligen inte var språkfilosof $i$ någon modern mening: han analyserade inte propositioner i sig utan mentala akter, som stod bakom dem. ${ }^{13}$

\section{Ross som rättsrealist}

$\mathrm{Nu}$ är det dags att återvända till Ross. Boken Towards a Realistic Jurisprudence 
torde vara viktig för Ross' utveckling därför att han i den tog det definitiva steget $\mathrm{i}$ riktning mot rättsrealism. Tesen $\mathrm{i}$ boken är nämligen den att alla dualistiska teorier, i vilka rättssystemet ses både som ett empiriskt faktum och ett normativt förpliktande system, bildar olösbara motstridigheter. Den lösning som Ross väljer är att det som är "normativt pliktande" måste tolkas på nytt. Vi såg redan tidigare att Ross förnekade existensen av vissa mentala akter. Vid mentala akter är det inte fråga om en riktig, verklig eller dylik föreställning, utan bara om ett skenfenomen, en rationalisering. Metafysiken uppstår just genom denna mekanism. Också pliktbegreppet måste omtolkas genom att visa i vilken mening det här är fråga om en rationalisering.

Det var mycket viktigt för Ross att man inte enbart reducerar rättsvetenskapen till rättssociologin. Men å andra sidan går han rätt långt $i$ att förvandla "det rättsligt förpliktande" till ett motiv eller en attityd för mänskligt handlande. Om en moralisk handlingsattityd är detsamma som en oegoistisk handlingsattityd, kan respekt för lagen uppfattas som en institutionell handlingsattityd. När vi i metafysisk mening talar om rättsligt förpliktande innebär detta egentligen att det "krävs" av befolkningen att var och en i viss mån borde tillägna sig en oegoistisk handlingsattityd, dvs. var och en måste visa respekt för lagen. Normativiteten av kravet är egentligen till sin natur rent ideologisk. Det ser ut som om den egoistiska handlingsattityden (rädslan för sanktionen etc.) hos Ross och det oegoistiska handlingsmotivet eller -attityden på sätt och vis skulle vara i samverkan. ${ }^{14}$

"The legal system is a social order characterized by having its foundation

in peculiar behaviour attitudes, such as are at the same time expressions of interested and disinterested impulses, and have taken their rise, developed, and established themselves by an inductive interaction between two motives, a fear of compulsion, and a belief in authoritative validity."15

På detta sätt var det möjligt att definiera objektet för den rättsvetenskapliga forskningen på nytt: forskningsobjektet är inte någon specifik juridisk normativitet som sedan skall klarläggas och justifieras, utan forskningen skall inriktas på vissa beteendeattityder och deras samverkan. Men Ross gick inte så långt som många s.k. amerikanska realister. Om man vill nå kunskap om rättsliga handlingsattityder, måste man enligt Ross ta i beaktande rättskällor - extern iakttagelse av domarbeteendet etc. räcker inte till. Men Ross var inte heller någon normativist: rättskällorna räckte inte, utan de måste på sätt och vis kompletteras med samhällsteoretiska uppgifter.

Om man vill sammanfatta vissa av den skandinaviska realismens karakteristiska drag, kan kanske följande lista presenteras: ${ }^{16}$

1) Rättsvetenskapen skall utforska verkligheten, vilket betyder att forskningen skall utreda menings- och motivationssammanhangen i socialt handlande.

2) Metafysiska antaganden godkänns inte. Juridiska begrepp såsom vilja, rättsplikt etc. måste omtolkas så att de i sin tur har en referens till verkligheten.

3) Rättsvetenskapen måste ha ett godtagbart filosofiskt fundament. 


\section{Den analytiska rättsfilosofen Ross}

På 1950-talet sker i Ross’ tänkande åter en viss nyaccentuering. Uppsala-skolans hägerströmska filosofi får åtminstone till en del ge plats för en ny bakgrundsfilosofi, den logiska empirismen. Redan underrubriken i Om ret og retfcerdighed bevisar detta: En indførelse i den analytiske retsfilosofi. Den största förändringen syns i hans sätt att förstå forskningens objekt: tidigare var det viktigast att utreda i vilken mening rätten var en del av verkligheten. Nu ökade intresset för den språkliga dimensionen i rätten. Den nya frågan lydde: vilken real mening har rättsvetenskapens propositioner? ${ }^{17}$

Förändringen betydde inte att Ross var tvungen att uppge alla sina tidigare utgångspunkter. Han var t.ex. ännu mycket intresserad av normernas giltighetsproblematik. Den tidigare uppfattningen om att rättslig giltighet måste omtolkas så att den hänvisar till uppkomsten av oegoistiska handlingsattityder kunde nu utvecklas vidare: rättsliga normer fungerar som direktiv vilka i viss mening kan användas som tolkningsschemata för mänskligt handlande, i fall människorna själva uppfattar dem som bindande. Det är inte fråga om något enkelt kausalsamband mellan normerna och handlandet, utan det är fråga om ett komplext menings- och motivationssamband. Det har påpekats att vissa hermeneutiska aspekter betonas i samband med denna omtolkning. ${ }^{18}$ Direktiv är ofta öppna och det ser ut som om de skulle vara riktade till hela befolkningen. Men detta är i strikt mening inte fallet. Direktiv riktas omedelbart enbart till domarna som är direktivens egentliga adressater. Rättsteoretiskt är det intressant att Ross nu måste omformulera betydelsen av den rättsliga giltigheten med hjälp av eller som en del av en s.k. domarideologi. ${ }^{19}$

Den nya accentueringen betydde inte att Ross skulle ha tappat intresset för rättens "påverkningsmekanismer" i samhället. 1950-talets Ross var säkert mera intresserad av rättens "liv" som tolkningsschemata för domarbeteendet än av rättens allmänna sociala funktioner. Detta berodde delvis på det faktum att den juridiska giltighetsproblematiken kunde fokuseras just på denna punkt. En annan möjlig förklaring är att han började bedriva ett mera rättsdogmatiskt arbete och t.ex. författade läroböcker i folk- och statsförfattningsrätt.

\section{Ross och straffrättsfilosofin}

Som redan noterades, var Ross egentligen en lång tid den internationellt kända kritiska rättsfilosofen bland representanterna för den skandinaviska realismen. Men det var andra, närmast Lundstedt och Ekelöf, som började med att "implementera" den skandinaviska realismens program (om man nu över huvud taget får använda ett sådant uttryck i detta sammanhang). När Ross sedan blev mera intresserad av straffrätten var den skandinaviska realismens höjdpunkt redan passerad.

I det följande kommer jag att i någon mån granska Ross' straffrättsfilosofi. Särskild uppmärksamhet kommer att fästas vid hans huvudverk på området, dvs. 
Skyld, ansvar och straff (1970) (On Guilt, Responsibility and Punishment, 1975). De mera snävt straffrättsdogmatiska aspekterna måste här utelämnas.

Redan i prologen förklarar han några av sina intentioner, t.ex. att den straffrättsliga teoretiseringen om skulden gynnas av att den straffrättsliga diskussionen relateras till den mera allmänna moraldiskussionen. En juridisk teori om skulden är enligt honom egentligen bara en precisering och upprepning av vissa moralidéer som anpassas för de särskilda krav som en juridisk institution ställer. Det kan sammanfattas som att all straffrättsjuridik enligt Ross på något sätt redan i sig har en moralisk ton. Ross vill idka komparativ forskning om rätt och moral för att visa att själva moralen har beteendestyrande funktioner: för rättens del torde detta redan vara självklart. Ett pragmatiskt synsätt på rätten var redan godkänt, men samma behövdes enligt honom också i moraltänkandet. ${ }^{20}$

Ross inleder sin bok, som egentligen är en samling essäer, med en analys av det som betecknas som skuld. Frågan är närmast om en begreppsanalys i den analytiska filosofins anda. Ansvar (och skuld) är som bekant ett bra exempel på

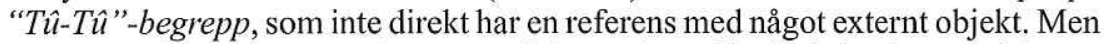
både "skuld" och "ansvar" kan trots allt ha en förnuftig funktion i användningen av språket. Normativa system, både moralen och rätten, existerar enligt Ross när man till deras normer anknyter en viss skyldighet att följa dem; men inte bara detta utan man måste förutsätta att alla som bryter mot normerna skall bemötas med klander. Detta är ett normativt krav, dvs. när man säger att en regel "är i kraft" betyder detta detsamma som att säga att detta de facto sker. I enskilda fall kan det hända att gärningspersonen inte har några skuldemotioner och ibland har vi skuldemotioner fast vi egentligen inte borde ha dem. För att klarlägga skuldens dimensioner börjar Ross med att noggrannt analysera teologiska skuldbegrepp och skuldupplevelser. ${ }^{21}$

Jag övergår nu till vissa specifikt juridiska frågor. I straffrätten är skuld en betingelse för ansvar, men vad är ansvar egentligen?22 Ross vill förändra perspektivet för såväl den straffrättsliga som den moralfilosofiska forskningen: det lönar sig inte att försöka definiera det materiella objektet för termen ansvar, utan man borde koncentrera sig på användningen av språket. Man måste först få veta vad som avses när det sägs att $\mathrm{A}$ är ansvarig för handlingen $\mathrm{y}$. Och den "ansvars"struktur som vi alltid möter är: personen A anses ansvarig för handlinger y inför domstolen $\mathrm{x}$. Därför måste två användningar av begreppet ansvar särskiljas: att vara ansvarig i den meningen att det är möjligt att klandras eller åtalas p.g.a. gärningen och att vara ansvarig i slutlig mening, dvs. att dömas till ansvar. Ross gör också vissa andra distinktioner, t.ex. en mellan att vara ansvarig i mera generell mening ("regnskabsansvar") och att bära ansvaret ("domsansvar"). ${ }^{23}$ Den första termen är vidare än den andra därför att den kan täcka varje möjligt ansvar för andras handlande, såsom t.ex. i politiken. Domsansvar betyder alltid att man har brutit vissa giltiga normer och man kan därför ställas till ansvar. I fall av vikarierande ansvar uppfylls båda kriterierna. Att någon är rättsligt 
ansvarig betyder att han enligt rätten kan ställas till ansvar. Med detta ordbruk hänvisas alltså alltid till rättssystemet.

"Ansvaret er udtryk for en retlig bedømmelse, og denne består igen $i$ et direktivistisk (normativt) krav som konklusion i en slutning: Da de og de kendsgerninger foreligger (kort: A's skyld); og da loven er sådan och sådan, følger det at A skal straffes. Altså, at A (efter dansk ret) er ansvarlig for $x$, kan omskrives til et (direktivistisk) krav om at A skal straffes, fordi han er skyldig; eller til en (indikativisk) påstand om, at et sådant krav følger når dansk ret bringes til anvendelse på foreliggende kendsgerninger:" 24

"At ansvaret er uden semantisk referens betyder ikke at ansvarsudsagn er illusoriske som genstandsløse. Deres funktion er at udtrykke sammenhoengen mellem skyld og straf, betingende kendsgerninger og betinget følge. De kan efter omstcendighederne anvendes således at opmarksomheden fortrinsvis rettes enten mod de betingende kendsgerninger; skylden; eller mod foclgen, kravet om straf." ${ }^{25}$

Detta samband behövs åter just därför att ett visst institutionellt men ändå samtidigt moraliskt element av klander är "närvarande" som en del av en straffrättslig rättstillämpning. ${ }^{26} \mathrm{Med}$ denna tanke är Ross benägen att lösa också den gamla straffteoretiska dispyten mellan retribution och prevention: att A straffas baserar sig på retribution, dvs. retribution är detsamma som att A hålls ansvarig för en viss normförbrytelse och dess juridiska sanktionering innehåller alltid ett visst element av klander. Men retribution är inte någonting som kunde särskiljas från själva rättstillämpningen. Retribution är inte något mål i sig, utan på den institutionella nivån måste straffrätten legitimeras med rent preventiva skäl. På detta sätt har retributionen en preventiv uppgift. ${ }^{27}$

Det ser ut som om Ross skulle försöka att inte bara lära jurister att se det moraltänkande som redan ligger inbyggt i juridiken, utan samtidigt vilja lära moralfilosofer att se det "juridiska" eller "normativa" $i$ det moraliska. Vad jag kan se förblir det en relativt öppen fråga vilken "moral" Ross vill börja med. Skall det vara den positiva, nuförtiden i samhället rådande empiriska moralen, eller något alternativ till denna?

Som en bra analytisk straffrättsfilosof försöker Ross "skapa ordning och reda" i den straffteoretiska debatten genom att först skilja mellan en rad olika typer av frågor som kan ställas. Tidigare hade bl.a. Hart på ett liknande sätt skiljt mellan "general justifying aim" och "distribution" av straff. ${ }^{28}$ Det tycks vara klart för Ross att många elementära frågor beträffande när och hur man borde skapa kriminaliseringar inte över huvud taget borde ses som filosofiska till sin natur, utan som empiriska: "Det er en opgave for den individual- og socialpsykologiske kriminologi at udvikle almindelige teorier om, gennem hvilken mekanik straffelovgivningen og dens håndhævelse i retsplejen er i stand til at indvirke dirigerende 
på samfundsmedlemmernes adfærd." ${ }^{29}$ Problemet torde för honom närmast vara att vi vet relativt litet om påverkningsmekanismerna för prevention på empirisk nivå.

Själv vill Ross heller inte, åtminstone inte i detta sammanhang, ge något definitivt svar på straffteoretiska frågor: man måste t.ex. skilja mellan olika kriminaliserade gärningstyper. ${ }^{30}$ Det skall påpekas att Ross' indelning av olika frågor också lämnar utrymme för vissa sådana frågor vars betydelse senare har ökat; jag avser här t.ex. diskussionen om juridiska och moraliska restriktioner beträffande lagstiftarens frihet att stifta strafflagar. ${ }^{31}$ Dessa har senare bearbetats närmast inom ramen för människorätts- och grundrättighetsdiskussionen. Ross framhäver inte enbart klassiska rättsstatliga rättviseprinciper som (formell) rättssäkerhet och den straffrättsliga legalitetsprincipen, utan ser det som möjligt att också materiella kriterier - t.ex. humanitetsskäl $1^{32}$ - kan ges vikt som sådana restriktiva principer. De kunde beaktas såväl vid stiftande av strafflagar som vid straffrättslig rättstillämpning.

Ross önskar visa att en stor del av den straffrättsteoretiska debatten helt enkelt baserar sig på missförstånd och att den därför egentligen är helt överflödig. En orsak till att situationen är denna är att man sällan har försökt ta reda på vad motståndaren egentligen har menat. Ross torde tänka sig att särskilt utilitaristiska kritiker har haft svårigheter att förstå att retributionsteoretikernas idéer endast sällan har innefattat ett faktiskt retributionselement: närmast har det varit frågan om att straff utdöms när lagen så kräver.

Ross tar själv ingen ställning i debatten. Han tycks favorisera tankesättet att ståndpunkter i olika filosofiska debatter inte får bestämma hur man skall tänka om straffrättsligt ansvar. En stor del av boken består egentligen just av en kritik av förslag som innebär försök att totalt eliminera den straffrättsliga begreppsapparaturen - särskilt skuldbegreppet. Som bekant är det här fråga om en mycket långvarig debatt inom den straffrättsliga teorin. Redan vissa kriminologer, som på 1800-talet tillhörde den s.k. positivistiska skolan, var attraherade av tanken att en vetenskaplig syn på världen förutsatte att determinism godkändes som utgångspunkt och att determinism inte kunde förenas med metafysiska antaganden om fri vilja etc. Dessa idéer rönte senare uppmärksamhet bland vissa extrema kretsar i den s.k. sociologiska skolan, som i en del av Europa var känd som "defénce social". ${ }^{33}$ Idén att en vetenskaplig syn på rättsliga fenomen förutsatte en hel nyordning av ansvarsproblematiken var populär särskilt bland psykiater och andra medicinare.

Vi kan notera att redan Harts bok innefattade en omfattande diskussion med Barbara Wootton och andra som ville avskaffa hela kravet på skuld för straffrättsligt ansvar. ${ }^{34}$ Ross behandlar inte riktningen lika diplomatiskt, utan försöker helt enkelt visa att Woottons argumentering är fylld av luckor. En orsak till att Ross ville lära moralfilosofi till medicinare var säkert att Olof Kinberg i Norden en längre tid hade propagerat för liknande tankar som Wootton. Konfron- 
tationen med den vetenskapliga positivismen var inte den första för Ross. Redan år 1933 hade han försökt visa att den franska sociologiska positivismens, t.ex. August Comtes, syn på "social fysik", som också innehöll "en positiv politik", bara var en metafysisk moralteori i ny dräkt. ${ }^{35}$

En viktig utgångspunkt i Ross' kritik av défence social var att man när man eliminerar skuldrekvisiten och inte försöker använda straffhot som ett beteendestyrande medel, löper risk att det inte mera finns gränser för statens befogenheter att kontrollera livet i samhället. ${ }^{36}$ Enligt Ross kan teoretisk kunskap om världen aldrig omedelbart innefatta eller befästa sådana normativa krav som skulle innebära att man borde eller måste inrikta sig enligt vissa målsättningar. Om man inte kommer ihåg detta har man kommit in på en farlig väg: sådana drag är karakteristiska för riktningar som kan ses som ett hot mot demokratin. Detta tema, demokratins försvar, var ju också viktigt för Ross. ${ }^{37}$

Som sagt uppfattade Ross dylik positivistisk kriminologi och sociologi som ett slags ny naturrättslära enligt vilken man kunde deducera normativa krav från deskriptiva teoretiska inställningar. Det här social-defensiva tänkandet var egentligen inte alls defensivt om man såg "försvaret" från brottslingarnas perspektiv, tvärtom, deras farliga personlighet var den omedelbara grunden för behandling och andra sociala sanktioner. De extrema representanterna för défence social var som bekant beredda att mera utvärdera farligheten hos gärningspersonen än farligheten av enskilda handlingar. ${ }^{38}$

Det finns emellertid en klar skillnad mellan å ena sidan Ross' syn, utformad som den är av en (tidigare) representant för skandinavisk realism och analytisk rättsfilosofi, och å andra sidan den tidigare defénce social -realismen. Positivister av den senare typen trodde sig direkt kunna inkludera även politisktmoraliska, dvs. ideologiska element, som delar av verkligheten. Det är inte fråga om en slump att Ross ville framhäva just dessa skillnader.

Barbara Wootton eftersträvde enligt Ross att upphäva både tillräknelighet och tillräkenbarhet som förutsättningar för straffansvar. Vad angår tillräkneligheten, ansåg Wootton att varken McNaghten-reglerna eller några andra regler var användbara. Hon var av den åsikten att hela frågan kunde förbigås: frågan är irrelevant för rationell kriminalpolitik. Likaså var hon av den åsikten att när man diskuterar preventionen beträffande brottsliga handlingar finns det inget behov av att lyfta fram sådana skuldfrågor som skulle ha att göra med tillräkenbarheten, alltså med frågan om uppsåt/oaktsamhet.

Vad beträffar den sistnämnda frågan anser Ross att Wootton tycker sig kunna beskriva och identifiera olika handlingar rent externt utan någon som helst hänvisning till gärningspersonens intentioner och motiv, vilket de facto inte är möjligt. En annan fråga är att strikt ansvar i straffrätten antagligen skulle minska den allmänpreventiva moralbildande verkan. ${ }^{39}$ Men det största felet var ändå att Wootton ansåg att alla medel som kunde tjäna det valda syftet, dvs. preventionen, måste tillgripas. I praktiken skulle detta, enligt Ross, ha lett till någon form av polisstat. 
Ross ser det själv som en brist att frågan, huruvida det finns rum för ansvarsbegrepp inom juridik och etik, alltför lätt sammankopplas med debatten om determinism och fri vilja. Man har en lång tid sett viljans frihet som en betingelse för att det skall finnas moraliskt och juridiskt ansvar. Därför anser deterministerna att när antagandet om fri vilja faller bort måste man också avstå från det därtill anknutna ansvarstänkandet. Men enligt Ross är detta inte fallet. De s.k. kompatibilisterna anser att det för ansvar inte krävs fri vilja utan det räcker med att man besitter handlingsfrihet. Det skulle alltså räcka med att man hade kunnat handla annorlunda. ${ }^{40}$

Enligt Wootton borde frågan om tillräknelighet bara ges utrymme vid fastställandet av lämpliga åtgärder. Wootton tycks tänka att skuld och klander inte kan betyda någonting om man enbart skall handla $\mathrm{i}$ enlighet med preventionsmålet, men som Ross så ofta har visat kan också klander ha en preventiv, beteendestyrande funktion. Han ser det som helt irrationellt att elementet av klander skulle elimineras för att öka preventionen och att man sedan skulle utgå från att den riktiga preventionen kunde uppnås enbart med vårdåtgärder. ${ }^{41}$

Ross medger att de olika ansvarskriteriernas exakta betydelse ofta är oklar. För att kunna klarlägga dessa uttrycks betydelse behövs både kriminologer och filosofer. Vi kan inte ta våra egna moralattityder för givna, eviga sanningar:

"Vi må tro, at den moralitet, der vokser frem i et samfund og upleves af individerne som selvgyldige krav, $i$ virkeligheten (d.v.s. uden at det er bevidst) dirigeres af behov og interesser. Det er derfor moralkritikkens opgave i analyse og kritisk reflektion at tage den positive, oplevede moralitet op til efterprøvelse, for at finde ud af, hvilke hensyn der har drevet den frem, og hvorledes den må vurderes $i$ lys af bevidst accepterede vurderingsprincipper:" 42

Wootton hade kritiserat de förslag som British Medical Association hade presenterat för att utvidga $\mathrm{McNaghten-} \mathrm{reglerna} \mathrm{i} \mathrm{fråga} \mathrm{om} \mathrm{nedsatt} \mathrm{tillräkneliga} \mathrm{personer.}$ BMA tar gärningspersonens förmåga att kontrollera sina handlingsimpulser som utgångspunkt. Wootton åter var av den åsikten att denna fråga inte kan besvaras med medicinvetenskaplig kunskap. Att vissa begrepp ännu inte kan definieras exakt innebär enligt Ross inget skäl att helt och hållet avvisa en sådan begreppsbildning.

Ett annat större och generellt tema för Ross är determinismens möjliga betydelse för ansvarsbegreppet. Här är det inte längre fråga bara om kritik av vårdideologin utan Ross torde vara av den åsikten att många kriminologer och sociologer är så förtjusta i sociologiskt tänkande och sociologiska forskningsmetoder att de tror sig kunna se på determinismen som något slags allmänvetenskaplig sanning, vilket utesluter möjligheten att mänskligt beteende skulle vara fristående från denna förklaringmodell. Enligt Ross har t.ex. Johs. Andenæs, som ju är känd för sin empiriska forskning om allmänpreventionen, gjort sig skyldig till en sådan felaktig slutsats. ${ }^{43}$ 
För att belysa problematiken presenterar Ross en hel rad argument som kan uppfattas som stöd för kompatibilism (förenlighetstesen) eller inkompatibilism (oförenlighetstesen). Den första åsikten tar det för givet att determinismen kan förenas med att enskilda individer kan sägas ha handlingsfrihet, dvs. människan kan sägas ha kunnat handla annorlunda hur hon än de facto har handlat. På detta kan sedan även möjligheten till klander byggas.

Denna diskussion kring determinism och ansvar är intressant inte minst därför att här tar Ross avstånd från Ingemar Hedenius' inkompatibilistiska uppfattningar som kunde ses som en extremposition bland skandinaviska realister. Ross har själv kallat den här typen av skandinavisk realism som behavioristisk: rättens giltighet reduceras till domarbeteendet. Hans egen modell att analysera rättslig giltighet är mera en syntes mellan psykologiska (domarideologin) och behavioristiska synpunkter (domarbeteendet). ${ }^{44}$ I sin moralfilosofi hade Hedenius kommit till den uppfattningen att determinismen inte lämnar någon plats för moraliskt ansvar, eftersom vårt moraliska medvetande tar det för givet att moraliskt ansvar förutsätter viljans frihet, dvs. att viljan inte får stå under påverkan av deterministiska krafter. ${ }^{45}$ Ross riktar sin Hedenius-kritik bl.a. mot att möjligheten till klander och moraliskt ansvar förnekas.

Redan antropologen och moralfilosofen Edward Westermarck hade bevisat att moralens utveckling hänger ihop med moralens pragmatiska dimensioner, vilket ingenting hade med indeterministiska antaganden att göra. Också Hedenius såg moralisk styrning i samhället som nödvändig men som en praxis som inte kunde underbyggas med vetenskapligt underlag. För Ross är juridiskt ansvar bara en form av "institutionaliserad" moral. Rätten fungerar som en beteendestyrande faktor därför att den har moraliskt innehåll. Moralen uppfattas pragmatiskt som ett medel i styrning av olika verksamheter; det räcker för Ross med att vi förstår hur moraliskt klander påverkar människor och hur detta är inkorporerat i såväl moraldebatt som straffrättsliga diskussioner. Vi behöver inte förkasta olika ansvarsstrukturer därför att vi inte kan bevisa deras exakta teoretiska innehåll. Enligt Ross borde debatten mellan determinism och indeterminism inte ges någon betydelse över huvud taget vid bestämmandet av det moraliska ansvarets betingelser. Naturligtvis borde moraliskt klander uttryckas bara i sådana fall där detta klander kan ha någon preventiv verkan; men detta godkänns även av indeterminister. ${ }^{46}$

Det är typiskt för Ross att han med sin digra beläsenhet och argumentation angriper olika "allmänna uppfattningar" som sedan bevisas vara helt oförnuftiga. Determinismdebatten är ett exempel på detta. Ross går igenom olika teologiska och vetenskapsfilosofiska tolkningar om determinism och visar att även många determinister tar det för givet att allt i världen inte kan förutses; förutsebarheten skulle t.ex. förutsätta att man borde ha fullständig information om utgångsläget, vilket aldrig kan vara fallet. En fullständig determinism är redan av logiska skäl problematisk. Den här diskussionen är naturligtvis särkilt intressant därför att 
Ross principiellt har försökt bygga hela sin rättsteori på den idén att giltighet och andra dylika "normativistiska" begrepp skall tolkas eller omvandlas så att de hänför sig till sociala fakta. ${ }^{47}$

En mera begränsad determinism är enligt Ross - och en rad andra - inte inkompatibel med moraliskt ansvar, snarare tvärtom:

"En begrcenset determinisme er ikke alene ikke uforenelig med moral, men vel endog en nødvendig forudscetning for den opfattet som pragmatisk teknik. Medens begransningen, som lige omtalt, garanterer meningsfuldheten af moral som indre oplevelse av overvejelse og beslutning $i$ agenten selv, garanterer lovmaessigheden i menneskelig adfard meningsfuldheden af moralen som pragmatisk teknik med det formål (den funktion) at påvirke menneskelig handlemåde."4s

Som en sista punkt, som delvis sammanhänger med determinism/ indeterminism-diskussionen, skall den analys uppmärksammas, som Ross ägnar åt satsen "han kunde ha handlat annorlunda". Det handlar alltså om en språkfilosofisk analys av satsen som i moralfilosofin har diskuterats som en modern motsvarighet till idéerna om viljans frihet: moraliskt ansvar och därmed klander förutsätter inte viljans frihet utan handlingsfrihet i den bemärkelse att personen i fråga kunde ha uppfyllt de krav som ställs för godtagbart handlande. På sätt och vis blir just denna analys den punkt där det moraliska och juridiska ansvarets huvudidéer fokuseras. Det är alltså fråga om den idé som den senare straffrättsliga litteraturen har kallat konformitetsprincipen.

Ross går igenom den filosofiska analysen av den ovannämnda satsen för att utreda om satsen har någon betydelse för determinism/indeterminism-debatten. Ross själv är av den åsikten att satsen inte förutsätter någon som helst bundenhet vid metafysiska idéer om viljans frihet. Enligt honom är naturvetenskaplig determinism likväl "inte oförenlig" med moralisk skuld och ansvar. ${ }^{49}$

Ross analyserar först vad "X kan A" betyder. Peter kan t.ex. spela piano, om han har förmåga, tillfälle och motivation att göra det. Det är alltså med hjälp av olika termer som satsen skall analyseras och omtolkas. Förmåga och tillfälle tillsammans är betingelser för att X har tillräcklig makt i situationen. Satsen "han kunde ha handlat annorlunda" är naturligtvis i sin utformning mera komplicerad än den enkla indikativformen "X kan A". Den är en kategorisk sats som kunde fortsättas eller så att säga kompletteras med en annan sats, t.ex. "om han hade haft tillfälle". 50

Rätt intressant är att Ross inte nöjer sig med den här "primära" meningsanalysen av satsen. Han tar nämligen i beaktande också en situation där personen i fråga inte kan emotses handla på ett förväntat sätt på grund av tvång eller annat dylikt hot även om det förväntade handlandet egentligen hade varit $i$ hans eller hennes makt. Förväntningen faller då bort därför att det skulle vara oskäligt att emotse ett sådant handlande $\mathrm{i}$ en tvångssituation: ${ }^{51}$ 
"Uanset at det må anerkendes at den tvungne faktisk kunne have handlet anderledes end han gjorde, er det ligefuldt velbegrundet at fritage ham for ansvar når trangen har varet af en sådan styrke, at det efter almindelig menneskelig erfaring og målestok ikke kunne forventes at han skulle have handlet anderledes end han gjorde. For, at det ikke "kunne forventes" vil netop sige at et menneske med normalt udviklet fornuft og pligtfølelse ville have handlet på samma måde i hans sted. Selvom altså det er misvisaende at sige om den tvungne, at han ikke kunne have handlet anderledes, er dog denne vending efter sin funktion på sin plads. For dens funktion er at fritage for ansvar:"

\section{Spår av skandinavisk realism och analytisk filosofi i den senare straffrättsforskningen}

Som redan antytts är det mycket svårt att isolerat försöka bedöma Ross' inflytande på straffrättsforskningen i Norden. Detta beror närmast på att en hel del av idéerna som Ross stod för redan tidigare hade utvecklats av andra forskare, som åtmistone till en del delade Ross' grundläggande uppfattningar om straffrättsforskning. Också Ross’ utveckling som rättstänkare försvårar saken. Trots att Ross hade mycket få "elever", försvåras saken även av det faktum att nästan alla viktiga nutida straffrättsforskare kan sägas dela vissà av hans grundåskådningar därför att hans tänkande väl kan förenas med den viktiga straffrättsideologiska riktningen som har kallats nyklassicism. Handlingsorientering, betoning av klandrandets moralbildande verkan, rättvisetänkande som genom en omtolkning t.ex. av skuldprincipen kunde rädda straffrättens anknytning till moraliska värden och principer; dessa ideologiska utgångspunkter kan accepteras av många.

Ross' tänkande kan möjligen ha fungerat som ett extra skäl för straffrättsforskarna att ta avstånd från den långt gående vårdideologin. Men egentligen började kritiken av vårdideologin redan mycket tidigare, åtminstone i Finland redan på 1960-talet. I Finland kan man redan vid denna tidpunkt tala om mera nyklassiska betoningar inom kriminalpolitiken. Debatten kring tvångsvårdsåtgärdernas kriminalpolitiska önskvärdhet var vid denna tid fortfarande i viss mån i.gång i Sverige och i Danmark, där detta tänkande också i praktiken hade haft flera anhängare än i Finland.

Eero Backman (1992, s 231) nämner följande straffrättsforskare som enligt honom står Ross och den bild om rätten som den skandinaviska realismen hade skapat nära: Ivar Agge, Johs. Andences, Anders Bratholm, Stephan Hurwitz, Nils Jareborg, Alvar Nelson, Ivar Strahl, Hans Thornstedt och Knud Waaben. Listan kan säkert kompletteras med betydligt flera namn, för Finlands del t.ex. Inkeri Anttila, Patrik Törnudd, Raimo Lahti, Tapio Lappi-Seppälä, Ari-Matti Nuutila osv. Men ju bredare perspektiv man väljer desto magrare blir resultatet. Egentligen skulle redan Brynolf. Honkasalos läroböcker kunna räknas med; i dem citeras - 
delvis klart godkännande - flera gånger Ekelöfs och Lundstedts tanke om straffets moralbildande verkan. ${ }^{52}$ Även Honkasalo var alltså öppen för att acceptera sådana åsikter, men som bekant var han med säkerhet ingen anhängare av nyklassicism. Han godkände också t.ex. behandlingsideologiska argument.

En viktig aspekt i den senaste straffteoretiska diskussionen, som möjligen ökar det allmänna vetenskapliga intresset för Ross' pragmatiska moralfilosofi, är det faktum att det nuförtiden åter talas allt mera om moraliska känslor och deras betydelse för den samhälleliga moralen. Detta tema hade ju redan utvecklats av Edward Westermarck i början av århundradet, och sedan förts vidare av skandinaviska realister och också av olika angloamerikanska etc. forskare. I finsk kriminologisk forskning kunde en studie om förlikning i straffmål nämnas som exempel. ${ }^{53}$ Intresset för känslornas roll i det straffrättsliga systemet begränsar sig alltså inte enbart till straffets moralbildande funktion.

Ross tar med sin straffrättsfilosofi del i debatten om den kriminologiska kunskapens betydelse för straffrättsligt ansvar. Han vill avvisa vissa försök att direkt grunda kriminalpolitiska åtgärder på kriminologiska uppgifter. Han vill dock inte avskärma kriminologin som vetenskap. Hans idé är endast att det måste finnas utrymme för äkta kriminalpolitiskt beslutsfattande; kriminalpolitik är inte bara tillämpning av vetenskaplig kunskap utan ett område där det finns alternativ. Detta beslutsfattande behöver goda "sociala ingenjörer" som förstår samhälleliga fenomen. Enligt Ross finns det inget hinder för att även jurister kan besitta sådana egenskaper.

På 1960-talet förändrades till stor del det vetenskapliga klimatet inom straffrättsforskningen. I Finland grundades ett första kriminologiskt forskningsinstitut. Straffrättsforskning bedrevs i allt större utsträckning i en omgivning där kriminologiska uppgifter fanns att tillgå. Forskning kring brottslighet, avvikande beteende $\mathrm{i}$ allmänhet och dess kontroll bedrevs inte bara av kriminologer $\mathrm{i}$ traditionell mening utan även av sociologer. Jag tror inte att Ross uppfattade detta som en utveckling i negativ riktning, så länge som man bara förstod hur den nya kunskapen om brottslighet kunde utnyttjas vid kriminalpolitiskt beslutsfattande.

I slutet av 1960-talet väcktes intresset bland jurister och särskilt bland rättsteoretikerna i Norden för analytisk filosofi. I Finland var Georg Henrik von Wright säkert det ledande namnet bland filosofer, och Aulis Aarnio kunde nämnas på det rättsteoretiska planet. Ross var i Finland säkert mera känd som rättsteoretiker än som straffrättstänkare. Detta berodde närmast på att det då $\mathrm{i}$ Finland egentligen inte bedrevs någon sådan straffrättslig forskning som var utpräglat (accentuerat) rättsteoretisk.

I Sverige var läget ett annat eftersom Nils Jareborg med sin doktorsavhandling från år 1969 och därefter med en rad andra straffrättsteoretiska studier hade påvisat relevansen av modern språk- och handlingsfilosofi för straffrättslig teoribildning. Trots att både Ross och Jareborg kan sägas vara representanter för en modern analytisk språkfilosofi, betyder detta inte att de har utgångspunkter 
som är fullständigt gemensamma. Jareborg bygger t.ex. sin framställning på en kognitivistisk värdeteori ${ }^{54}$, medan den skandinaviska realisten Ross snarare kan ses som en representant för den emotivistiska värdeteorin. I ett senare skede ansåg dock Ross att också de moraliska problemens art kan klarläggas genom lingvistiska analyser. Jareborgs och Ross' uppfattning om generalpreventionens påverkningsmekanismer ser åtminstone i viss mån olika ut, osv. ${ }^{55}$ Men också vissa gemensamma nämnare kan anges, t.ex. analysen och betoningen av konformitetsprincipen. ${ }^{56}$ En annan likhet mellan de två forskarna är att bägge noggrannt skiljer mellan straffrättssystemets olika nivåer när frågor om straffets syften behandlas. Analyser av detta slag har varit mycket viktiga också för den straffrättsliga teorins utveckling i Finland. Trots att den analytiska filosofin metodiskt fick spela en växande roll $i$ analyser av juridiska termer och juridiskt språk, betydde detta inte att värderingsfrågor eller kriminalpolitiska aspekter helt och hållet skulla ha blivit åsidosatta.

Ross' straffrättsfilosofi var defensiv till sin natur: han ville negera oriktiga argument och påståenden, särskilt de som är filosofiska till sin natur. Hans bakgrund i den skandinaviska realismen syns däri att han hela tiden är mycket försiktig beträffande filosofins inflytande på juridiken även om detta också är hans egen synvinkel. Trots sin bakgrund hade han hela tiden en viss förståelse för de ansvarsstrukturer och den "erfarenhet" som via dem är inbyggd i vår straffrättsjuridik. Juridiskt ansvar är mera långtgående strukturerat än moraliskt ansvar och därför kan moraldiskussionen dra nytta av juridiken.

Det nyklassiska tänkandet i Norden har egentligen hela tiden haft ett visst pragmatiskt särdrag: den vikt de juridiska formerna har uppfattas inte ha något särskilt juridiskt värde i sig. Juridiska former - t.ex. den juridiska begreppsapparaturen som krävs i analysen av skuld i straffrätt - behövs däremot för att garantera individernas handlingsfrihet i samhället. Av pragmatiska skäl anser man det således vara viktigt att man vid konstruktionen av ett straffrättsligt ansvarsbegrepp behåller en viss begreppsapparatur. Men detta betyder inte att man önskar återvända till den slags begreppsjuridiska konstruktivism, som är känd från tidigare kontinental och även nordisk juridik. Detta var säkert också Ross' avsikt: dålig metafysik måste alltid avvisas.

Ross har möjligtvis från angloamerikanskt rättstänkande till Norden "förmedlat" vissa rättsfigurer som senare har fått starkare fotfäste. Det är t.ex. möjligt att hans kritik av uppsåtsteorierna har medverkat till att termen "recklessness" (likgiltighet) lancerades i Finland på 1970-talet. ${ }^{57}$

Även några sådana aspekter kan nämnas som begränsar Ross' inflytande på den nutida debatten. Ross har under hela sin vetenskapliga karriär varit en mycket systematisk forskare, och också hans uppfattning om rätten kan anses vara "systematisk". Han betraktar rätten som ett stort system som fungerar som en institutionaliserad moral. Denna synvinkel har som följd att Ross kraftigt betonar de rättsliga normernas betydelse som beteenderiktande normer. Intresset för att 
motivera och förstå den positiva allmänpreventionen är så dominerande, att ett antal andra mål och funktioner egentligen inte alls ges något utrymme.

Tiden för en mycket renodlad nyklassicism är egentligen redan nu förbi, såväl i de teoretiska diskussionerna som i konkret lagreformeringsarbete. Nya sanktioner - t.ex. i Finland samhällstjänst och ungdomsstraff - vittnar om en förändring av klimatet. ${ }^{58}$ Konflikt och restitution är nya nyckelord. Förlikningsverksamheten har vunnit mera uppmärksamhet än tidigare, och man kan förutse att också straffets förhållande till vård åter kommer att lyftas fram och nu mera konstruktivt och inte bara kritiskt. Längre ser man inte heller moralen enbart som handlingsnormer.

Som ett sista påpekande vill jag nämna att också den analytiska filosofins ställning i den rättsteoretiska och rättsfilosofiska debatten har försvagats. Naturligtvis kan man säga att den analytiska filosofins syn på moralfrågor är aktuell ännu i dag, när olika nya versioner om liberalt tänkande har fått ökad betydelse. Men också nya filosofiska bakgrundsteorier har dykt upp, liksom den moralfilosofiska debatten har fortsatt. Även helt nya temata har dykt upp. Ett relativt sett nytt försök att bygga upp moralisk och juridisk normativitet baserar sig på diskursteorin som en procedural moralteori. T.ex. Jürgen Habermas har försökt rekonstruera en demokratisk rättsstat på detta sätt. ${ }^{59}$ Diskursteorin kan ses som en vidareutveckling av Kants moralfilosofi, som ju Ross explicit förkastade. Diskursteorin igen kan ses som en form av argumentationsteori, vilket uttryckligen innebär att det blir möjligt att behandla också etisk och juridisk argumentation inom den. Detta i sin tur är viktigt med tanke på diskussioner och teoribildning t.ex. på den straffrättsliga ansvarslärans nivå.

Ross började sina studier om ansvar med att granska språkbruket. Efter 1970talet har klimatet förändrats och en rad nya ansvarsfrågor har dykt upp inom både den etiska som den juridiska diskussionen. T.ex. i Finlands grundlag (Regeringformen $14 \mathrm{a} .1$ §) lyder en bestämmelse: "Var och en bär ansvar för naturen och dess mångfald samt för miljön och kulturarvet." Om de kommande generationerna har rättigheter, då har vi möjligtvis ett visst ansvar i förhållande till dem också. Hans Jonas har skrivit om "Principen ansvar". ${ }^{60}$ Paul Ricœur anser i sin tur att risk- och solidaritetsidéerna har börjat allvarligt konkurrera med de gamla idéerna om ansvar. ${ }^{61}$ Också i juridisk litteratur behandlas allt mera frågor som fördelning (allokering) av straffansvaret inom företag. I alla nordiska länder finns något slags reglering om juridiska personers straffansvar.

Den analytiska filosofin var ofta skeptisk till möjligheterna att kunna säga något vettigt om allmänna begrepp och allmänna principer etc. I den moderna rättsstatsideologin är man inte längre nöjd med att bara beskriva det som vi språkligt avser när vi talar om rätten, utan det förutsätts att man måste kunna diskutera olika utvecklingsmöjligheter av rätten osv. Vi tänker oss rättsstaten inte bara som en form utan som en form med innehåll. Människorättstänkandet samt betoningen av grundrättigheterna kan ses som en öppning i denna riktning. Ross 
skulle antagligen ha varit nöjd med att man ytterligare försöker konkretisera den demokratiska rättsstatens juridiska struktur, men det kan lika väl hända att hade Ross, varit tvungen att välja mellan Harts och t.ex. Dworkins allmänna utgångspunkter, hade han valt att följa Hart.

\section{LITTERATUR:}

Aarnio, Aulis (1997)

Reason and Authority. A Treatise on the Dynamic Paradigm of Legal Dogmatics. Aldershot et al 1997.

Backman, Eero (1992)

Oikeustiede yhteiskuntatieteenä. Tutkimuksia oikeustieteen luonteesta erityisesti rikosoikeuden kannalta. (Rättsvetenskapen som samhällsvetenskap) Helsinki 1992.

Bjarup, Jes (1978)

Skandinavischer Realismus. Hägerström - Lundstedt - Olivecrona - Ross. Freiburg i.Br., München 1978.

Bjarup, Jes (1982)

Reason, Emotion and the Law. Studies in the Philosophy of Axel Hägerström. Aarhus 1982.

Ekelöf, Per Olof (1942)

Straffet, skadeståndet och vitet. En studie över de rättsliga sanktionernas verkningssätt. Uppsala 1942.

Habermas, Jürgen (1992)

Faktizität und Geltung. Beiträge zur Diskurstheorie des Rechts und des demokratischen Rechtsstaats. Frankfurt a.M. 1992.

Hart, H.L.A. (1968)

Punishment and Responsibility. Oxford 1968.

Helin, Markku (1988)

Lainoppi ja metafysiikka. Tutkimus skandinaavisen oikeusrealismin tieteenkuvasta ja sen vaikutuksesta Suomen siviilioikeuden tutkimuksessa vuosina 1920-1960. (Dogmatiken och metafysiken.) Vammala 1988.

Honkasalo, Brynolf (1965)

Suomen rikosoikeus. Yleiset opit. Ensimmäinen osa. Toinen painos. (Finlands straffrätt. Allmänna läror I), 2. upplagan. Helsinki 1965.

Häthén, Christian (1990)

Straffrättsvetenskap och kriminalpolitik. De europeiska straffteorierna och deras betydelse för svensk strafflagstiftning 1906-1931. Lund 1990.

Jareborg, Nils (1975)

Värderingar. Stockholm 1975.

Jareborg, Nils (1988)

Essays in Criminal Law. Uppsala 1988.

Jareborg, Nils (1992)

Straffrättsideologiska fragment. Uppsala 1992.

Jareborg, Nils (1994)

Straffrättens ansvarslära. Uppsala 1994.

Jonas, Hans (1984)

Das Prinzip Verantwortung. Versuch einer Ethik für die technologische zivilisation. Frankfurt a.M. 1984.

Koskinen, Pekka (1994)

Nya accentueringar inom det straffrättsliga påföljdssystemet i Finland. Nordisk Tidsskrift for Kriminalvidenskab (81), 1994, Nr. 1, 67-76. 
Lahti, Raimo (1990)

Recodifying the Finnish Criminal Code of 1889. I R. Lahti - K. Nuotio (red.), Towards a Total Reform of Criminal Law. Helsinki 1990, 55-85.

Lappi-Seppälä, Tapio (1987)

Rangaistuksen määräämisestä I. Teoria ja ylcinen osa (Om utdömande av straff I). Vammala 1987.

Lundstedt, Anders Vilhelm (1920)

I. Principinledning. Kritik av straffrättens grundåskådningar. Uppsala 1920.

Lundstedt, Anders Vilhelm (1936)

Die Unwissenschaftlichkeit der Rechtswissenschaft. Zweiter Band. Erster Teil. Strafrecht. Vertragsrecht. Deliktische Haftung. Uppsala 1936.

Lundstedt, Anders Vilhelm (1956)

Legal Thinking Revised. My Views on Law. Stockholm 1956.

Nuotio, Kimmo (1998)

Teko, vaara, seuraus (Gärning, fara, följd). Helsinki 1998.

Ricœur, Paul (1995)

Le Juste. Paris 1995.

Ross, Alf (1929)

Theorie der Rechtsquellen. Ein Beitrag zur Theorie des positiven Rechts auf Grundlage dogmenhistorischer Untersuchungen. Leipzig und Wien 1929.

Ross, Alf (1933)

Kritik der sogenannten praktischen Erkenntnis. Kopenhagen 1933.

Ross, Alf (1946)

Towards a Realistic Jurisprudence. Copenhagen 1946.

Ross, Alf (1959/1966)

On Law and Justice. Berkeley, Los Angeles 1959. (Om ret og retfærdighed. En indførelse i den analytiske retsfilosofi. 1953. 2. oplag 1966.)

Ross, Alf (1967)

Hvorfor Demokrati? 2. Udgave. København 1967.

Ross, Alf (1968)

Directives and Norms. London 1968.

Ross, Alf (1970)

Skyld, ansvar og straf. København 1970.

Ross, Alf (1974)

Forbrydelse og straf. Analytiske og reformatoriske bidrag til kriminalrettens almindeliga del. København 1974.

Ross, Alf (1975)

On Guilt, Responsibility and Punishment. Berkeley and Los Angeles 1975.

Ross, Alf (1979)

Über den Vorsatz. Studien zur dänischen, englischen, deutschen und schwedichen Lehre und Rechtssprechung. Baden-Baden 1979.

Straffrättskommitténs betänkande 1976:72 (Finland). Helsingfors 1977.

Takala, Jukka-Pekka (1998)

Moraalitunteet rikosten sovittelussa. (Moralkänslor vid förlikning av brott) Helsinki 1998. 
Noter:

1 Föredrag vid den III Nordiske Workshop i Strafferet vid Köpenhamns Universitet och i Roskilde (16.-18.4.1999).

3 Se t.ex. Helin 1988, 6.

4 Se även Ross 1974, 55.

s Se t.ex. Backman 1992, 179-235; Bjarup 1978, passim; Helin 1988, passim.

6 Vad som avses är alltså "den rationella idealism" som som förgrundsgestalt hade Christopher Jacob Boström (1797-1866).

7 Här enligt Helin 1988, 19-29. Se därtill t.ex. Bjarup 1982, 109-199.

8 Ross 1933, 429-431, 435 (435).

9 Lundstedt 1936, 26-47.

${ }^{10}$ Se Lundstedt 1920, t.ex. 21-39, 74-80; Lundstedt 1956, 217-240.

Häthén (1990, 191-194 (193)) ser Lundstedts polemik som en "mycket sen svensk variant av den tidige och politiskt radikale von Liszts läror". Ett bättre sätt att tolka Lundstedts betydelse kunde vara att se honom som en av de första skandinaviska representanterna för den moderna straffrättsliga funktionalismen. Detta torde vara även Backmans åsikt, se Backman 1992, 190-202, särskilt 197.

1 Ekelöf 1942, 23-25.

12 Ekelöf 1942, 25-26.

${ }_{13}$ Helin 1988, 30-34.

${ }^{14}$ Se t.ex. Helin 1988, 144-152.

15 Ross 1946, 89-90.

${ }^{16}$ Se också listan i Helin 1988, 44.

17 Se här den grundliga analysen i Helin 1988, 157-163.

18 Helin 1988, 162-163.

${ }_{19}$ Ross 1966, 41-51; Aarnio 1997, 67-74.

${ }^{20}$ Ross 1970, 7-10.

${ }^{21}$ Ross 1970, 1-24. En motsvarande relatering utförs också av Paul Ricœur (1995, 41-70), men intentionen är en annan: enligt Ricœur måste den analytiska filosofin som bakgrund kompletteras med fenomenologiska och hermeneutiska uppfattningar.

${ }^{22}$ Ross 1970, 29: "Hensigten med nærværende afhandling er at yde et bidrag til en afklaring af ansvarsbegrebet og derigennem godtgøre en sådan analyses betydning for problemerne om skyld som ansvarsbetingelse."

${ }^{23}$ Ross 1970, 30. Fördelningen syns inte vara särskilt illustrativ. Om fördelningen se också Backman 1992, 223.

${ }^{24}$ Ross $1970,36$.

${ }^{25}$ Ross 1970, 38.

${ }^{26}$ Se t.ex. Ross 1968, 82-92. Om "formalt" eller "institutionellt" rättsmedvetande se Ross 1959, 5258.

${ }^{27}$ Ross 1970, 45-47.

${ }^{28}$ Hart 1968, 1-13.- Jareborg har, som bekant, likaså försökt analytiskt skilja mellan flera olika frågor, t.ex. mellan "varför" och "hur" -frågor. Se Jareborg 1988, 105-121.

${ }^{29}$ Ross 1970, 75.

${ }^{30}$ Ross 1970, 76-77.

${ }^{31}$ Ross 1970, 77-90.

32 Ross 1970, 87. - Senare har Lahti försökt utveckla en modell, där ett rationellt straffrättssystem uppfattas beakta såväl effektivitets-, rättvise- som humanitetshänsyn. Se t.ex. Lahti 1990, 50-59.

${ }^{33}$ Se t.ex. Nuotio 1998, 161-164.

${ }^{34}$ Hart 1968, 158-185.

${ }^{35}$ Ross $1933,245-274$.

${ }^{36}$ Se även Hart 1968, 181-182.

${ }^{37}$ Se t.ex. Ross 1967, 172-189. 
${ }^{38}$ Ross 1970, 101-108.

${ }^{39}$ Ross 1970, 121-122.

${ }^{40}$ Ross 1970, 126-131.

${ }^{41}$ Ross 1970, 131-138.

${ }^{42}$ Ross 1970, 138.

${ }^{43}$ Ross 1970, 158.

${ }^{44}$ Ross 1966, 88-89.

45 Ross 1970, 171-175.

${ }^{46}$ Ross 1970, 184-195.

${ }^{47}$ Ross 1970, 198-218; Ross 1959, ix-xi.

48 Ross 1970, 214.

${ }^{49}$ Ross 1970, 236.

${ }^{50}$ Ross 1970, 236-244.

${ }^{51}$ Ross 1970, 245-252 (251).

${ }^{52}$ Honkasalo 1965, 21-33.

${ }^{53}$ Takala 1998, passim.

54 Jareborg 1975, 7: "Lösningen innebär... att värdedimensionen "avemotionaliseras" och att det egendomliga intresset för särskilda värdeord, betraktade nästan som magiska, kan ersättas av att man i stället ägnar sig mer väsentliga sakfrågor."

${ }^{5}$ Se t.ex. Jareborg 1994, 323-326. Men t.ex. texten i Jareborg 1992, 234-236, kunde klart bli accepterad också av Ross.

56 Jareborg hade ännu i Handling och uppsåt $(1969$, 361) en snävare definition av konformitetsprincipen än Ross. Ross' definition godkänns t.ex. av Lappi-Seppälä $(1987,139)$.

57 Se härom Ross 1974, 22-31; Straffrättskommitténs betänkande 1977, 111.

${ }^{58}$ Se t.ex. Koskinen 1994, passim.

59 Habermas 1992, passim.

${ }^{60}$ Jonas 1984, passim.

${ }^{61}$ Ricœur 1994, 41-70.

Adresse: Jur.dr., tf. professor i straff- och processrätt Kimmo Nuotio Institutionen för straff- och processrätt

P.B. 4

FIN- 00014 Helsingfors universitet 